\title{
Ecléa Bosi, a grande amiga
}

\section{BETTY MINDLIN ${ }^{I}$}

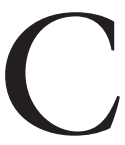

INQUENTA ANOS de amizade e admiração por Ecléa (extensivos a Alfredo, seu marido) extravasam qualquer expressão escrita. Não sei precisar quando se deu nosso primeiro encontro - e ela, estudiosa da memória, me puxaria a orelha. É como se sempre tivesse feito parte de minha vida. Mas lembro que, amigas próximas, eu grávida de meu filho mais velho, fomos juntas visitar Carmen Junqueira, a quem eu só conhecia de vista. No cenário acolhedor do apartamento, com lareira acesa e flechas, ouvimos o mito kamaiurá da cobra e da origem dos invasores, imaginando o céu estrelado xinguano. Vejo agora Ecléa, nesse dia, como uma fada a conduzir meu destino aos povos indígenas, que ela sempre defendeu com ardor. Todos os anos, em seu curso de Psicologia Social, Ecléa promovia um debate sobre a questão indígena e falava da vida e obra dos irmãos Villas Bôas. Uma de suas muitas causas de justiça; também em cada turma dedicava aulas a Iara Iavelberg, sua colega de classe e amiga, assassinada pela ditadura na mesma época, em 1971.

Ecléa era uma psicóloga de renome, professora, muito antes de eu estudar antropologia com Carmen. Um dia, ao pôr-do-sol, sentadas as duas contemplando o rio Paraíba, em uma casa de campo de meus pais, ela observou, em uma de suas tiradas inesquecíveis: "Não sei o que você vai ser, que forma irá tomar, não posso imaginar!”. Embora formada em economia e professora universitária, eu bem gostaria de ter uma resposta dela naquele momento, pois não sabia que caminho iria seguir. Sua dúvida de adivinha foi um alento, abertura para uma metamorfose desconhecida.

Tínhamos muitos interesses em comum. Simone Weil nos uniu. Não foi Ecléa, e sim um grande amigo, colega do curso científico no Colégio Bandeirantes, Gabriel Leite da Silva Dias, a me fazer ler L'enracinement et La condition ouvrière. Mas o mergulho intenso, a profundidade da leitura da obra da escritora por Ecléa, que resultaram anos mais tarde na antologia por ela preparada, com um ensaio introdutório esclarecedor, são impressionantes, bem mais radicais e completos do que estaria ao meu alcance realizar. Ecléa e Simone me parecem à vezes confundir-se, na exigência de um mundo sem classes e desigualdades, na febre de compreender os destituídos, viver nas mesmas condições, jamais aceitar privilégios de qualquer ordem, compartilhar sempre a arte, a literatura, a música com os que nunca tiveram acesso à esfera da criação e da liberdade. Ambas, intransigentes, não fazem concessão ao analisar o trabalho industrial, a tecnologia massacrante a que são condenados os operários, homens e mulheres. Fazem uma radiografia impiedosa do crime que é submeter seres humanos à rotina repetitiva e à linha de montagem numa fábrica, mesmo se não existisse 
a exploração do trabalho. Gente transformada em peças, almas aprisionadas em um modo de produzir aceito pela sociedade como natural. A crítica de Ecléa e Simone é rara, tem sido abandonada mesmo pelos movimentos sociais.

Recusar consumo supérfluo, ou mesmo o parco necessário, quando a maior parte da humanidade não tem sequer o mínimo, é um traço de caráter que Simone Weil bem cedo revelou. Conta-nos Ecléa, na introdução, que Simone "Ao ganhar um anel de presente, com três anos, faz todos rirem com sua resposta: O luxo não me agrada!". ${ }^{1}$

Felizmente o temperamento de Ecléa não é monástico ou rígido, nisto se distanciam. Teve a plenitude da experiência de amor, família, filhos, netos, profissão bem-sucedida e estável, muita alegria e brincadeira, amigos em profusão, tolerância, gosto por roupas bonitas e elegantes como expressão artística, cozinheira de pratos deliciosos. Ainda bem que Ecléa não seguiu Simone, que deixou de comer porque em países distantes a população passava fome, nem foi à guerra procurando usar armas de fogo por causas justas como a Guerra Civil Espanhola... Foi porém valente e ousada na batalha contra a energia nuclear, pela ecologia e preservação ambiental, com campanhas que iniciou há décadas e perseguiu sem cessar. Em meses recentes, quando lemos Svetlana Alexandrovna Alexievitch, conversamos muito sobre o que talvez seja a maior tragédia da humanidade, o perigo nuclear exposto pela bielorrussa ao descrever Chernobyl. Stella e Chico Whitaker contam que foram levados por Ecléa a estudar e a dedicar todas as suas forças ao assunto, o que fazem com generosidade admirável. Ecléa relata em uma entrevista a Mariluce Moura para a Fapesp, em 2014, que quarenta anos antes fez um apelo a Carlos Drummond de Andrade para que se juntasse à luta; ele aceitou o desafio, “estudou a questão e escreveu um artigo lindo intitulado 'Se eu fosse deputado', publicado no Jornal do Brasil”. Contra Angra dos Reis 3, Ecléa novamente divulgou o artigo, incluído em um manifesto que todos nós, seus amigos, mais que solidários, assinamos e espalhamos a seu pedido.

Em O tempo vivo da memória, ensaios de psicologia social, Ecléa escreve um ensaio sobre o campo de Terezin que é uma das mais pungentes páginas sobre o nazismo que já li. Não estive no que resta do campo, mas visitei o museu de Praga sobre Terezin - e as palavras de Ecléa ecoavam terríveis em mim enquanto eu percorria as poucas salas e o cemitério judeu adjacente. Em tudo que ela escreveu há esse dom de revelar a crueldade inacreditável a que pode chegar uma sociedade - contraposta à beleza, à poesia, ao amor pelos outros que mesmo nas piores condições algumas pessoas são capazes de exibir.

Quantos livros Ecléa me fez ler! Um dos seus numerosos presentes foi Cartas a D., de André Gorz, na tradução que ela promoveu, livro amoroso tristíssimo, escrito quando ele perdeu a mulher. Bem antes, eu adorava e costumava dar para meus alunos na FGV, do mesmo autor, um livro sobre a divisão social do trabalho, que tudo tinha a ver com a análise de Ecléa e Simone Weil. Eu nunca ouvira falar de Natalia Ginzburg, quando Ecléa me recomendou o Léxico 
familiar, que então li em inglês; ela é hoje uma das minhas escritoras preferidas, que li inteirinha em italiano. A leitura das poesias completas de Rosalía de Castro também me veio por Ecléa, com a cuidadosa tradução que ela fez, há muitas décadas, e imediatamente me deu. E muitos, muitos outros, sempre conversamos sobre leituras.

Em Velhos amigos, um primor de livro, de 2003, Ecléa revela-se poeta e ficcionista, embora todos os episódios sejam verdadeiros. Alguns são trágicos com final feliz, como "Pinocchio em Auschwitz", que faz lembrar um conto de Primo Levi, no qual dois judeus em um campo de concentração conseguem conversar sozinhos por minutos num dia de chuva, dentro de um cano, e discutem a existência de Deus. Outros nos fazem viajar por paisagens mineiras de Ouro Preto, com versos de Cecília Meireles, Drummond e Bandeira, ou por Goiás, em paragem rosiana bordada de buritis, na qual a narradora é tida como maga e curandeira, o que na verdade a autora Ecléa era. Do frio do "Natal em Florença" ouvi muito dela, quando ficou com Alfredo uma temporada na cidade, hospedados em um quartinho galgado apenas por escadas em um andar alto, quase sem aquecimento ou água quente, sovinados pela proprietária. Cada capítulo faz soar acordes adormecidos dentro de nós, novas melodias. Imagino a alegria de Ecléa quando sua filha Viviana escreveu um belo artigo justamente sobre esse livro, na homenagem feita à sua mãe no Instituto de Psicologia da USP, publicada em $2008 .{ }^{2}$ Que mãe não se derreteria com a leitura tão especial de uma filha?

Agora releio Memória e sociedade, lembranças de velhos, com percepção renovada, cada vez mais próxima estou da mesma faixa de idade. Que desabrochar a conversa com Ecléa deve ter desencadeado nos que lhe contaram sua história. Creio tomar consciência pela primeira vez de como o ângulo dos idosos contrasta com o dos mais novos. Além de me emocionar ao seguir como puxam o fio do novelo de suas vidas e de seu tempo, catadupas de lembranças minhas, sobretudo da infância, vão nascendo, imitando o processo dos entrevistados. Estes são oito, dos quais quatro mulheres. De uma delas muito ouvi falar: é bisavó de meus sobrinhos-netos Mhira e Rhavi, pois Malu, neta de D. Jovina, casou com meu sobrinho Rodrigo. D. Jovina Álvares Rocha Pessoa e seu marido, o grande cientista Dr. Samuel Barnsley Pessoa, foram militantes na política, comunistas e firmes opositores da ditadura militar. No livro, publicado em 1979, antes da abertura, têm um pseudônimo, mas os familiares aparecem com os nomes verdadeiros e pelas datas é possível identificá-los. Em 1988, ao ver de manhã a notícia do falecimento de $\mathrm{D}$. Jovina, e embora ainda não conhecesse ninguém da família, fui ao enterro com Mauro Leonel, que clandestino, aos dezenove anos, procurado pela polícia, eles haviam escondido em sua casa em 1968 ou 1969, por bastante tempo. Mauro defendia naquele dia seu mestrado, mas fez questão de ir antes ao cemitério. Na entrevista ela nada fala de um ato heroico como esse, em tempos nos quais hospedar um fugitivo era um risco de prisão e tortura. Ou se falou, Ecléa a protegeu, ainda era a ditadura... 
Fui à cerimônia de livre-docência de Ecléa, inesquecível a bela "arguição" de Marilena Chauí, que assim, com aspas, é a apresentação de Memória e sociedade em forma de livro. Era uma alegria presenciar as falas e as respostas de Ecléa.

O foco na velhice a fez criar e dirigir por 21 anos o programa da Terceira Idade na USP, excepcional no tema e na ligação universidade/sociedade, tão ausente ainda em muitos sentidos. Ecléa me apresentou a algumas das alunas participantes, interessantíssimas. Orgulhava-se muito de ver o entusiasmo que as aulas despertavam, misturando alunos regulares com os mais velhos experientes, vindos de fora da instituição, cerca de 100 mil idosos acolhidos nas duas décadas, talvez a maioria sem muita instrução formal. Ela me deu as publicações que fez, comentava muito, mas que pena tenho de não ter acompanhado mais de perto e ido às aulas que atingiam múltiplos departamentos e disciplinas, algo tão inventivo para a educação como um todo!

Ler e reler Ecléa faz senti-la tão perto, como se estivesse sentada ao lado, lembrando mais o que vivemos, estendendo os comentários. Ela é, talvez, a pessoa mais surpreendente que conheci. Tudo que dizia, de chofre, de modo inesperado, parecia sair de um bolso mágico, eram achados, ideias em que ninguém tinha pensado, imprevisíveis, despertavam, faziam enxergar. A coragem: ela conta em algum lugar como apavorou um ladrão, quando abriu a porta da cozinha e o viu; ela interrompera uma leitura de Kant e se espantou tanto que um ser humano pudesse invadir o lar de outro, que o interpelou com veemência - o pobre coitado deixou cair a peixeira e fugiu, com ela atrás... Suas personagens, praticamente todas verídicas, causam-nos dor e melancolia pelo sofrimento, pobreza, injustiças e tragédias vividas, reveladoras do absurdo que continua a ser a nossa organização social; ao mesmo tempo são modelos de humanidade, de afeto, de amor, procuram trabalhar com perfeição, abrigam e sustentam crianças abandonadas sem ter meios, voltam-se para instrui-las, e sempre combatem, lutam para obter mudanças. O Brasil contém traços que nos deixam perplexos: como é possível conservar ética e bondade em ambientes tão degradados? É Ecléa que os fotografa, através de lentes sensíveis, esperançosas, atingindo o imo de cada pessoa, ela própria dolorida, poética, feliz.

Tantos gestos delicados de Ecléa me percorrem. O par vermelho-escuro de sapatinhos de couro que ela deu ao meu primeiro filho Manu, que guardei até se desfazerem em pó; o vestidinho bordado de flores quando nasceu minha filha Inês; décadas depois, brinquedinhos de corda e hélices para o banho, bichinhos exóticos para meus netos Olivia e Heitor, este quatro anos mais novo que a menina. Flores, livros, telefonemas de aniversário, de preocupação com doentes, convites, almoços. Seu orgulho ao mostrar na casa onde moraram por décadas os canteiros, as árvores crescendo plantadas por ela, as verduras, o trabalho manual quase de roça.

O mundo fica pálido sem ela...

São Paulo, 31 de julho de 2017 


\section{Notas}

1 Ecléa Bosi (Org.) Simone Weil, A condição operária e outros estudos sobre a opressão. Rio de Janeiro: Paz e Terra, 1979.

2 Viviana Bosi, "Velhos amigos. Sobre Ecléa Bosi e outros trabalhos". São Paulo, Psicologia USP, v.19 n.1, jan./mar. 2008.

Betty Mindlin é doutora em Antropologia pela Pontifícia Universidade Católica de São Paulo (PUC-SP), autora de Diários da floresta (Terceiro Nome, 2006) e outros. @ - arampia@uol.com.br ; arampia.mindlin@gmail.com

Recebido em 6.9.2017 e aceito em 25.9.2017.

I Instituto de Estudos Avançados, Universidade de São Paulo, São Paulo, São Paulo, Brasil. 
